\title{
Seed Diversity of Indigenous Field Peas (Pisum sativum L.) Germplasm Collection in Oman
}

\author{
Nadiya A. Al-Saady ${ }^{1}$, Saleem K. Nadaf ${ }^{1}$, Ali H. Al-Lawati ${ }^{1} \&$ Saleh A. Al-Hinai ${ }^{2}$ \\ ${ }^{1}$ Oman Animal \& Plant Genetics Resources Center, The Research Council, Al-Athiba, Sultanate of Oman \\ ${ }^{2}$ Directorate General of Agriculture \& Livestock Research, Ministry of Agriculture, Al-Seeb, Sultanate of Oman \\ Correspondence: Saleem K. Nadaf, Oman Animal \& Plant Genetics Resources Center, The Research Council, P.O. \\ Box 1422, PC 130, Al-Athiba, Sultanate of Oman. Tel: 968-2230-5884. E-mail: saleem.nadaf@oapgrc.gov.om
}

\author{
Received: August 1, $2018 \quad$ Accepted: September 3, $2018 \quad$ Online Published: October 15, 2018 \\ doi:10.5539/jas.v10n11p523 \\ URL: https://doi.org/10.5539/jas.v10n11p523
}

The research was financed by HM Research Grant No. SR/AGR/CROP/07/01 of the Sultan Qaboos University, Muscat, Oman.

\begin{abstract}
Pea (Pisum sativum L.) is a field crop cultivated in most countries of the Arabian Peninsula for both food and fodder consumption during winter. This paper presents the results of indigenous germplasm collections in Oman and assessment of their seed diversity. 27 seed samples/accessions of field peas were collected during collecting missions of indigenous legume crops from 2008 to 2011. South Batinah-coastal governorate represented by Rustaq (15) had the highest, followed by Dhahira \& Buraimi governorates (8), Al-Dakhliya (Interior) governorate (2), Sharqiya (eastern) governorate (1) and North Batinah-coastal governorate (1). Seed accessions were found diverse for three seed traits and seed color. Seed length varied from $0.305 \mathrm{~cm}$ to $0.720 \mathrm{~cm}$ whereas seed width varied from $0.295 \mathrm{~cm}$ to $0.690 \mathrm{~cm}$. 100-seed weight ranged from $4.500 \mathrm{~g}$ to $21.9 \mathrm{~g}$. With respect to seed color, six accessions viz. Collection No. 25 (tan-light), No. 78 (dark green, mottled), No. 82 (light green), No. 173 (dark green, dark brown, mottled), No. 178 (brownish green, mottled) and No. 314 (cream, light pink) were homogenous (pure) whereas the remaining 21 seed accessions were heterogeneous (mixture) with various colors such as white cream, cream, light green, tan, light brown, dark brown and black with mottled nature. The collections were grouped into 10 genetically diverse clusters based on the Principal Component Analysis (PCA) using seed traits which revealed significant contribution of seed length $(34.378 \%)$ and 100 -seed weight $(34.182 \%)$ to the total variation existing in indigenous field pea germplasm collected across all the governorates of Oman.
\end{abstract}

Keywords: diversity, collections, seed characters, seed color, pea

\section{Introduction}

Oman with the characteristic location has its northern part that represents Asian countries and its southern part, to the African continent in both climate and culture. It is the second largest country in the Arabian Peninsula with 85473.10 ha of agricultural land under cultivation (MAF, 2017). Fruits occupy 36.11\% followed by perennial and annual fodder crop species (39.40\%), vegetables (19.72\%) and field crops (4.77\%). Of the field crops, field pea (Pisum sativum L.) is considered as an integral crop among the few farmers who grow it for both food and green fodder (MAF, 2005).

Pea being one of the oldest domesticated crops is grown during winter in temperate and subtropical regions of the world for both food and fodder. Canada is the major producer followed by USA, India, Russia, France and China (Gixhari et al., 2014). It is known for its ability to fix atmospheric nitrogen to improve soils and protein source (Santalla et al., 2001; Esposito et al., 2007). It is grown throughout Oman in both plains and mountains as a winter crop from November to March. Its exact area, productivity and yield figures are not documented. The seeds can be consumed fresh and green as a part of salad or as vegetable. Dried seeds are also consumed after cooking. The plant can be used as green or dry forage.

In peas seed size is considered as an important trait as it directly influences productivity (Syed et al., 2014). The seed sizes in field pea range from $<12 \mathrm{~g}$ per 100 seeds and $27 \mathrm{~g}$ (Bhuvaneswari et al., 2017). In this respect, the 
consumer market in general shows preference for a seed standard from medium to large (15 to $20 \mathrm{~g})$ (Anonymous, 2018). Genetic diversity in the crop species is the key for improvement and development of effective conservation strategies (Hodgkin, 1997; Egbadzor et al., 2013; Mafakheri et al., 2017). Knowledge of genetic diversity available in the indigenous germplasm is very useful for promoting the efficient use of genetic variations in breeding programs through proper selection of cross combination of parents. There are several studies undertaken on genetic diversity of pea populations not only in the past (Hoey et al., 1996; Simioniuc et al., 2002; Taran et al., 2005; Esposito et al., 2007; Zahir et al., 2007; Yadav et al., 2009) but also recently (Kumari et al., 2013; Kole et al., 2015; Ouafi et al., 2016; Khan et al., 2016; Bhuvaneswari et al., 2017) using both morphological and yield characters, and molecular markers.

In Oman, a range of ecotypes of field crops including that of field pea is grown mainly for their dual food value, and inherent interest due to diverse agro-climatic conditions. However, due to fluctuating land use patterns and the gradual shift in cultivation of high-yielding commercial crops, the indigenous germplasm of field crop species, including field pea is slowly getting extinct. Since early 1980s, several collecting missions were carried out in Oman either independently or jointly with national and international organizations to collect and conserve germplasm of crops grown (Al-Saady et al., 2014, 2018a, 2018b). During these missions the most of the landraces of alfalfa, wheat, barley and grain legumes like chickpea, faba bean, cowpea, lentil, fenugreek etc. including field peas were collected and conserved in local conservation facilities. In continuation of above activities, a series of joint collection missions between the Sultan Qaboos University and the Ministry of Agriculture \& Fisheries of Oman were undertaken from different sites within all the governorates of Oman during 2008-2011 to conserve the genetic diversity of vast indigenous germplasm available in legume crops of Oman. This paper presents the results of collecting missions of indigenous germplasm of field pea in addition to a brief account of their diversity in respect of three seed traits, having marketing significance.

\section{Materials and Methods}

Seven exploration trips for the collection of indigenous germplasm of alfalfa and food legumes like chickpea, faba bean, cowpea, lentil, field pea, mung bean and pigeon pea, and the medicinal legume fenugreek were undertaken from April 2008 to March 2011 in different Governorates of Oman with the support of the staff of Agriculture Development Centers of the Ministry of Agriculture and Fisheries following standard method of collecting missions (IPGRI, 1995; Hay \& Probert, 2011) from individual farmers, farmers-fields and stores, and Agriculture Development Centers with passport data and site descriptions including GPS data, electrical conductivity and $\mathrm{pH}$ of soil and water samples (Table 1). Remote and unexplored localities were prioritized.

The area covered during the trip lied between coastal and interior plains from 12-1983 m altitude. The collecting routes were systematically followed as per the plan in each of seven exploration trips in all the governorates. The collecting sites within the wilayats of governorates were located at least $25 \mathrm{~km}$ distant as they were so chosen to avoid collecting several seed samples of similar genotype.

A random sampling method was applied for most leguminous crops, where populations were large, otherwise, it was selective. Sampling was done from farmers' household stores and from harvested lots, together with individual sampling from fields. Samples were in the form of pods or seed. Standard passport data for each accession were recorded at the time of collection, including crop name, botanical name, local name of the variety or landrace, village, wilayat and Governorate and sample type, sample method, farmer's name, source of collection, and any special feature of the collection, including indigenous knowledge (IK), if any. Each accession was subsequently assigned an indigenous serial collection number according to collection, irrespective of crop species.

Descriptions of each site were recorded with respect to some soil and edaphic characteristics. Soil EC and $\mathrm{pH}$ was measured using field EC and $\mathrm{pH}$ measuring meters. Slope angle and aspect were assessed using an inclinometer and compass. The longitude and latitude of each collecting site and its altitude were recorded using a Magellan 315 GPS meter (Table 1). Attempts were made to collect root nodules from selected sites for applied microbiological studies. Indigenous food grain legume accessions were collected from 110 sites of which indigenous field pea accessions were collected from 25 sites across all the governorates of the Sultanate.

Seed characters such as seed length and width $(\mathrm{cm})$, test weight (1000 seed), seed color and nature of seed samples (pure or mixture) were determined in the laboratory according to Dijkstra and van Soest (1986). The principal component analysis (PCA) was performed in the extraction of the components using correlated matrix from the crop collection data using XLSTAT software (XLSTAT, 2017). 


\section{Results}

During collecting missions of land races of legume crops, 27 seed samples/accessions of field pea (Pisum sativum L.) were collected. South Batinah-coastal governorate represented by Rustaq had the highest accessions, collected (15), followed by Dhahira \& Buraimi governorates with 8 accessions. Governorates of Al-Dakhliyah (Interior) with two and Sharqiya-eastern area and North Batinah-coastal governorates with one each, had least number of accessions collected (Table 1).

The collection sites varied in their characteristics and altitude. Altitude ranged from $274 \mathrm{~m}$ at site No. 51 of Al Ghasahb, wilayat Rustaq to $1983 \mathrm{~m}$ at site No. 24 of Belad Sait, wilayat Rustaq of Batinah South governorate (Table 1). Soil characteristics were also varied. Sites ranged in soil texture from sands, sandy loam, sandy clay, sandy clay loam, clay to loam. Soils were hard, firm or loose, variable-loose to crust and friable. With respect to drainage, soils were either imperfect, free or variable. Soil pH ranged from 3.1 (Site No. 61, Nezooh, wilayat Rustaq, Batinah South governorate) to 9.0 (Site No. 50, Al-hodineeyah, wilayat Rustaq, Batinah South governorate). Soil EC varied from $0.6 \mathrm{dSm}^{-1}$ (Site No.7, Al-Blaad, wilayat Manah, Batinah South) to $9 \mathrm{dSm}^{-1}$ (Sites No. 56 of Atayeeb, No. 57 of Al-Mahdoot and No. 61 of Nezooh of wilayat Rustaq, Batinah South governorate). Soil color ranged from light brown to brown.

Table 1. The sites/locations in different villages, wilayats/districts and governorates/states from where indigenous field pea (Pisum sativum L.) accessions were collected, along with their latitudes, longitudes and altitudes

\begin{tabular}{|c|c|c|c|c|c|c|c|c|}
\hline Sl. No. & Site No. & Collection No. & Governorate & Wilayat & Village/location & Latitude $(\mathrm{N})$ & Longitude (E) & Altitude $(\mathrm{m})$ \\
\hline 1 & 7 & OMA 19 & Interior & Manah & Manah Al Blaad & $22^{\circ} 47.88^{\prime}$ & $57^{\circ} 35.98^{\prime}$ & 430 \\
\hline 2 & 9 & OMA 25 & Interior & Nizwa & Al-Ain, Jabel Akhdar & $23^{\circ} 04.07^{\prime}$ & $57^{\circ} 39.29^{\prime}$ & 1829 \\
\hline 3 & 23 & OMA 64 & Batinah South & Rustaq & Haat & $23^{\circ} 11.34^{\prime}$ & $57^{\circ} 24.52^{\prime}$ & 1978 \\
\hline 4 & 24 & OMA 72 & Batinah South & Rustaq & Balad Sait & $23^{\circ} 11.16^{\prime}$ & $57^{\circ} 23.51^{\prime}$ & 1983 \\
\hline 5 & 25 & OMA 74 & Dhahira & Ibri & Bilad Al-Shahoom & $23^{\circ} 23.26^{\prime}$ & $56^{\circ} 57.57^{\prime}$ & 884 \\
\hline 6 & 26 & OMA 78 & Dhahira & Ibri & Bilad Al-Shahoom & $23^{\circ} 23.94^{\prime}$ & $56^{\circ} 57.91^{\prime}$ & 793 \\
\hline 7 & 27 & OMA 81 & Dhahira & Ibri & Bilad Al-Shahoom & $23^{\circ} 23.71^{\prime}$ & $56^{\circ} 59.01^{\prime}$ & 924 \\
\hline 8 & 28 & OMA 82 & Dhahira & Ibri & Bilad Al-Shahoom & $23^{\circ} 22.96^{\prime}$ & $57^{\circ} 00.57^{\prime}$ & 947 \\
\hline 9 & 30 & OMA 96 & Dhahira & Ibri & Alablaah & $23^{\circ} 04.84^{\prime}$ & $56^{\circ} 54.14^{\prime}$ & 580 \\
\hline 10 & 31 & OMA 105 & Dhahira & Ibri & Baroot & $23^{\circ} 14.55^{\prime}$ & $57^{\circ} 02.47^{\prime}$ & 716 \\
\hline 11 & 33 & OMA 118 & Dhahira & Dank & Aqaib-Kumairah & $23^{\circ} 56.15^{\prime}$ & $56^{\circ} 16.87^{\prime}$ & 860 \\
\hline 12 & 37 & OMA 123 & Dhahira & Yanqul & Al-Bouwerdah & $23^{\circ} 38.06^{\prime}$ & $56^{\circ} 29.76^{\prime}$ & 586 \\
\hline 13 & 38 & OMA 134 & Dhahira & Yanqul & Al-Bouwerdah & $23^{\circ} 41.89^{\prime}$ & $56^{\circ} 30.33^{\prime}$ & 623 \\
\hline 14 & 43 & OMA 137 & Batinah South & Rustaq & Amq & $23^{\circ} 17.45^{\prime}$ & $57^{\circ} 19.72^{\prime}$ & 285 \\
\hline 15 & 44 & OMA 147 & Batinah South & Rustaq & Al-Ayeer & $23^{\circ} 12.79^{\prime}$ & $57^{\circ} 27.56^{\prime}$ & 723 \\
\hline 16 & 50 & OMA 149 & Batinah South & Rustaq & Al hodineeyah & $23^{\circ} 11.15^{\prime}$ & $57^{\circ} 37.81^{\prime}$ & 769 \\
\hline 17 & 51 & OMA 154 & Batinah South & Rustaq & Al Ghasahb & $23^{\circ} 24.97^{\prime}$ & $57^{\circ} 25.92^{\prime}$ & 274 \\
\hline 18 & 52 & OMA 159 & Batinah South & Rusaq & Almari & $23^{\circ} 27.89^{\prime}$ & $57^{\circ} 02.19^{\prime}$ & 678 \\
\hline 19 & $55^{*}$ & OMA 164 & Batinah South & ADC, Rusaq & AL Dahir & - & - & - \\
\hline 20 & 56 & OMA 170 & Batinah South & Rustaq & Atayeeb & $23^{\circ} 25.40^{\prime}$ & $57^{\circ} 09.78^{\prime}$ & 557 \\
\hline 21 & 57 & OMA 173 & Batinah South & Rustaq & Almahdooth & $23^{\circ} 30.52^{\prime}$ & $57^{\circ} 11.42^{\prime}$ & 482 \\
\hline 22 & $59^{*}$ & OMA 178 & Batinah South & ADC, Rustaq & - & - & - & - \\
\hline 23 & $60^{*}$ & OMA 181 & Batinah South & ADC, Rustaq & - & - & - & - \\
\hline 24 & 61 & OMA 185 & Batinah South & Rustaq & Nezooh & $23^{\circ} 28.92^{\prime}$ & $57^{\circ} 17.21^{\prime}$ & 344 \\
\hline 25 & 66 & OMA 198 & Batihah South & Nakhal & Alqoorah & $23^{\circ} 05.38^{\prime}$ & $57^{\circ} 44.20^{\prime}$ & 1322 \\
\hline 26 & 108 & OMA 267 & Sharqiyah & ADC, Ibra & - & - & - & - \\
\hline 27 & 130 & OMA 314 & Batinah North & Sohar & Wadi Hibi & $23^{\circ} 53.19^{\prime}$ & $56^{\circ} 32.27^{\prime}$ & 615 \\
\hline
\end{tabular}

Note. *Samples collected at ADCs (Agriculture Development Centers) located in wilayats of the governorates.

\subsection{Variability in Seed Characters}

The indigenous field pea accessions, collected, had large variation with respect to all the seed characters studied, i.e. seed length $(\mathrm{cm})$ and width $(\mathrm{cm}), 100$-seed weight $(\mathrm{g})$ and seed color (Table 2). Seed length varied from $0.305 \mathrm{~cm}$ (Collection No. 78 at Site No. 26 of Bilad Al-Shahoom, Ibri, Dhahirah) to $0.720 \mathrm{~cm}$ (Collection No. 25 
at Site No. 9 of Al-Ain, Jabal al-Akhdar, Nizwa, Interior); seed width ranged from $0.295 \mathrm{~cm}$ (Collection No. 78 at Site No. 26 of Bilad Al-Shahoom, Ibri, Dhahirah) to $0.690 \mathrm{~cm}$ (Collection No. 25 at Site No. 9 of Al-Ain, Jabal al-Akhdar, Nizwa, Interior); 100-seed weight ranged from $4.500 \mathrm{~g}$ (Collection No. 78 at Site No. 26 of Bilad Al-Shahoom, Ibri, Dhahirah) to $21.9 \mathrm{~g}$ (Collection No. 25 at Site No. 9 of Al-Ain, Jabal al-Akhdar, Nizwa, Interior). With respect to seed color, six accessions - Collection No. 25 (tan-light) of Site No. 9 at Al-Ain, Jabal al-Akhdar, Nizwa, Interior, Collection No. 78 (dark green, mottled) of Site No. 26 at Bilad Al-Shahoom, Ibri, Dhahirah, Collection No. 82 (light green) at Site No. 28 of Bilad Al-Shahoom, Ibri, Dhahirah, Collection Nos. 173 (dark green, dark brown, mottled) and 178 (brownish green, mottled) of Site Nos. 57 and 59 of Al-Mahdooth Hajer Bani Omer, Rustaq, Batinah South, and Collection No. 314 (cream, light pink) of Site No. 130 of Wadi Hibi (Al-Sham), Sohar, Batinah North governorate were homogenous (pure). The remaining 21 seed accessions were heterogeneous (mixture) with seeds of various colors ranging from white cream, cream, light green, tan, light brown, dark brown, black, mottled. The results of analysis of seed colors of these collections indicated the presence of as many as 25 groups of which two groups had two collections each (Collection Nos. $74 \& 81$ and Collection Nos. 173 \& 181) and remaining 23 seed accessions - Collections Nos. 19, 25, 64, 72, 78, 82, 96, 105, $118,123,134,137,147,149,154,159,164,170,178,185,198,267$ and 314, formed groups of their own due to a unique combination of seed colors.

Table 2. Variation among seed characteristics of 27 indigenous field pea genotypes/accessions collected

\begin{tabular}{|c|c|c|c|c|c|c|c|}
\hline S1. No. & Collection No. & $\begin{array}{l}\text { Length } \\
(\mathrm{cm})\end{array}$ & $\begin{array}{l}\text { Width } \\
(\mathrm{cm})\end{array}$ & $\begin{array}{l}100 \text { seed } \\
\text { weight }(\mathrm{g})\end{array}$ & Seed color & Seed Color & Governorate \\
\hline 1 & OMA 19 & 0.67 & 0.635 & 20.6 & Homogeneous & Tan light & Interior \\
\hline 2 & OMA 25 & 0.72 & 0.69 & 21.9 & Heterogeneous & Green, tan & Interior \\
\hline 3 & OMA 64 & 0.69 & 0.405 & 16.2 & Heterogeneous & Green, tan, white cream, black & Batinah South \\
\hline 4 & OMA 72 & 0.66 & 0.61 & 19.5 & Heterogeneous & Light green, $\tan$ & Batinah South \\
\hline 5 & OMA 74 & 0.545 & 0.485 & 10.3 & Heterogeneous & Dark green, brown, mottled & Dhahira \\
\hline 6 & OMA 78 & 0.305 & 0.295 & 4.5 & Homogeneous & Dark green, mottled & Dhahira \\
\hline 7 & OMA 81 & 0.56 & 0.53 & 9.9 & Heterogeneous & Dark green, brown, mottled & Dhahira \\
\hline 8 & OMA 82 & 0.715 & 0.65 & 20.4 & Homogeneous & Light green & Dhahira \\
\hline 9 & OMA 96 & 0.645 & 0.585 & 16.3 & Heterogeneous & Green, white cream, tan, pinkish & Dhahira \\
\hline 10 & OMA 105 & 0.62 & 0.585 & 16.8 & Heterogeneous & Pinkish, cream, green & Dhahira \\
\hline 11 & OMA 118 & 0.575 & 0.54 & 14.5 & Heterogeneous & White cream, tan, green, brown & Dhahira \\
\hline 12 & OMA 123 & 0.59 & 0.55 & 14.8 & Heterogeneous & White cream, tan, green, mottled & Dhahira \\
\hline 13 & OMA 134 & 0.605 & 0.555 & 16 & Heterogeneous & Green, light brown, tan, white cream, mottled & Batinah South \\
\hline 14 & OMA 137 & 0.655 & 0.615 & 19.5 & Heterogeneous & White cream, green & Batinah South \\
\hline 15 & OMA 147 & 0.6 & 0.585 & 11.2 & Heterogeneous & Light green, white cream & Batinah South \\
\hline 16 & OMA 149 & 0.52 & 0.475 & 11 & Heterogeneous & White cream, light green, dark brown, mottled & Batinah South \\
\hline 17 & OMA 154 & 0.59 & 0.545 & 13.2 & Heterogeneous & Dark blackish green, mottled light brown & Batinah South \\
\hline 18 & OMA 159 & 0.605 & 0.56 & 11 & Heterogeneous & Dark green, light green, brown, mottled & Batinah South \\
\hline 19 & OMA 164 & 0.59 & 0.55 & 14.3 & Heterogeneous & White cream, light green, dark green, tan, mottled & Batinah South \\
\hline 20 & OMA 170 & 0.505 & 0.48 & 8.2 & Heterogeneous & Dark green, dark brown, mottled & Batinah South \\
\hline 21 & OMA 173 & 0.585 & 0.535 & 11.6 & Homogeneous & Dark green, dark brown, mottled & Batinah South \\
\hline 22 & OMA 178 & 0.51 & 0.49 & 7.9 & Homogeneous & Brownish green mottled & Batinah South \\
\hline 23 & OMA 181 & 0.55 & 0.535 & 9.9 & Heterogeneous & Dark green, dark brown, mottled & Batinah South \\
\hline 24 & OMA 185 & 0.65 & 0.64 & 17.8 & Heterogeneous & White cream, light green, light brown, dark brown & Batinah South \\
\hline 25 & OMA 198 & 0.59 & 0.525 & 14.6 & Heterogeneous & Green, dark green, dark brown, tan, mottled & Batinah South \\
\hline 26 & OMA 267 & 0.645 & 0.59 & 14.2 & Heterogeneous & Pinkish brown, dark brown, black & Sharqiya \\
\hline 27 & OMA 314 & 0.685 & 0.645 & 21.2 & Homogeneous & Cream, light pink & Batinah North \\
\hline \multicolumn{8}{|c|}{ Statistical Parameters } \\
\hline \multicolumn{2}{|c|}{ Minimum } & 0.305 & 0.295 & 4.500 & & & \\
\hline \multicolumn{2}{|c|}{ Maximum } & 0.720 & 0.690 & 21.900 & & & \\
\hline \multicolumn{2}{|c|}{ Mean } & 0.597 & 0.548 & 14.104 & & & \\
\hline \multicolumn{2}{|l|}{ S.E. $( \pm)$} & 0.016 & 0.016 & 0.872 & & & \\
\hline
\end{tabular}




\subsection{Principal Component Analysis}

In order to comprehend with which combination type of three seed characters the indigenous field pea germplasm of Oman would attain high quality in terms of their commercial value, the Principal Component Analysis was performed. The PCA transforms the number of associated traits into a smaller number of variables as PCs and simplifies the complex data. The Scree plot of the PCA (Figure 1) showed that the first two eigenvalues corresponded to the major proportion of the variance in the dataset.

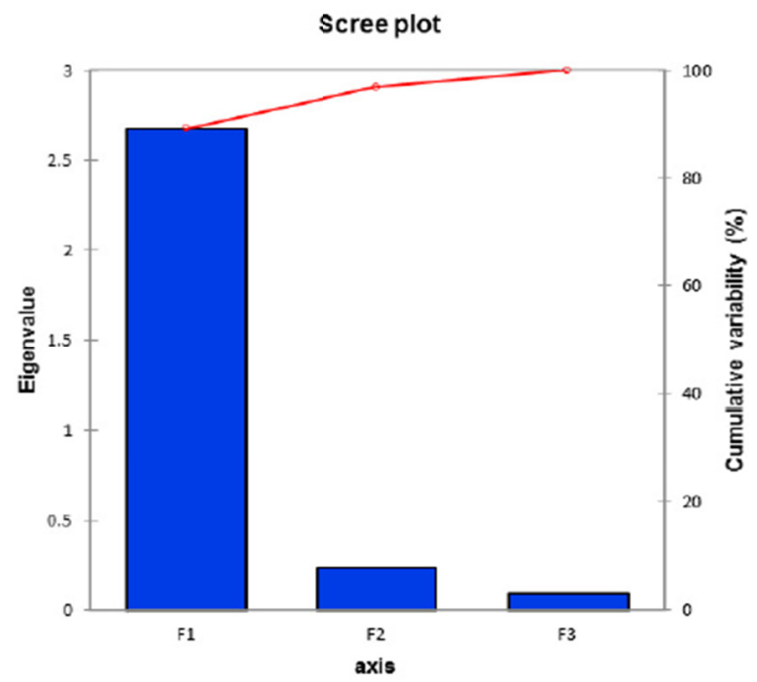

Figure 1. Scree plot showing eigenvalues in response to three principal components, PCAs or Factors (F1 to F3) for three seed variables/characters in field pea accessions

The first two PCAs extracted from the complicated components accounted to $96.915 \%$ with PC 1 having eigenvalue of 2.676 and PC 2, just 0.232 (Table 3). The first PC or factor accounts for maximum variability in the data in comparison with succeeding components or factors. The PCA grouped the estimated field pea variables into three main components of which PC 1 or factor 1 accounted for about $89.191 \%$ of the variation; PC 2 or factor 2 for $7.724 \%$ and PCA 3 or factor 3 for only $3.085 \%$ (Table 3 ).

Table 3. Eigen values and percent variance of principal components to total variation in indigenous field pea accessions

\begin{tabular}{llll}
\hline Principal Components (PC's) or Factors & Eigen value & \% Variance & Cumulative variance \\
\hline PC 1 or F1 & 2.676 & 89.191 & 89.191 \\
PC 2 or F2 & 0.232 & 7.724 & 96.915 \\
PC 3 or F3 & 0.095 & 3.085 & 100.000 \\
\hline
\end{tabular}

The first PC was positively influenced by seed length with the value measuring 0.959 and 100 -seed weight with 0.956 whereas the second PC was also influenced positively by seed width but with lower value $(0.398)$. However, third PC was also associated with seed length which had low value (0.219) (Table 4). Similarly, only positive and significant correlation values (r) were found between three seed traits, studied viz. seed length vs seed width $\left(0.806^{*}\right)$, seed length vs 100 -seed weight $\left(0.907^{* *}\right)$ and seed width vs 100 -seed weight $\left(0.799^{*}\right)$ (Table 5).

Table 4. The principal component values of three seed size characters in 27 indigenous field pea accessions

\begin{tabular}{llll}
\hline Variables/Characters & PC 1 & PC 2 & PC 3 \\
\hline Seed length $(\mathrm{cm})$ & 0.959 & -0.180 & 0.219 \\
Seed width $(\mathrm{cm})$ & 0.917 & 0.398 & -0.008 \\
100 Seed-Weight $(\mathrm{g})$ & 0.956 & -0.202 & -0.211 \\
\hline
\end{tabular}


Table 5. Correlation coefficients between seed size characters of indigenous field pea accessions

\begin{tabular}{llll}
\hline & Seed length $(\mathrm{cm})$ & Seed width $(\mathrm{cm})$ & 100 Seed-Weight $(\mathrm{g})$ \\
\hline Seed length $(\mathrm{cm})$ & 1 & $0.806^{*}$ & $0.907^{*}$ \\
Seed width $(\mathrm{cm})$ & & 1 & $0.799^{*}$ \\
100 Seed-Weight $(\mathrm{g})$ & & & 1 \\
\hline
\end{tabular}

In terms of per cent contribution of seed traits to the PCs, both seed length and 100-seed weight together contributed to the extent of $68.56 \%$ to $\mathrm{PC} 1$ and $99.92 \%$ to $\mathrm{PC} 3$ whereas seed width alone had $68.48 \%$ contribution to PC2 (Table 6).

Table 6 . The percent contribution of variables (three seed size characters) to three principal component values in 27 indigenous field pea accessions

\begin{tabular}{llll}
\hline Variables/Characters & PC 1 & PC 2 & PC 3 \\
\hline Seed length $(\mathrm{cm})$ & 34.378 & 13.945 & 51.677 \\
Seed width $(\mathrm{cm})$ & 31.440 & 68.485 & 0.075 \\
100 Seed-Weight $(\mathrm{g})$ & 34.182 & 17.570 & 48.248
\end{tabular}

The scatter of 27 indigenous field pea accessions in biplot graph of the first two principal components as $\mathrm{X}$ and Y-axes clearly indicated that field pea accessions were clustered and occupied over all the four quadrants of the graph to classify the accessions into 10 clusters where the accessions belonging to the same group were closely positioned to form clusters in whichever quadrants of the graph they belonged due to their similarities (Figure 2). The number of accessions in the clusters ranged from single (Clusters V, VI, VII and X) to the highest of 5 (Cluster III and Cluster IX). The remaining 4 clusters had accessions ranging from 2 (Cluster I), 3 (Cluster IV) to 4 (Clusters II and VIII). The accessions of the clusters either belonged exclusively to the same governorates like Batinah South governorate (Cluster I) or to different governorates (Clusters II, III, IV, VIII and IX).

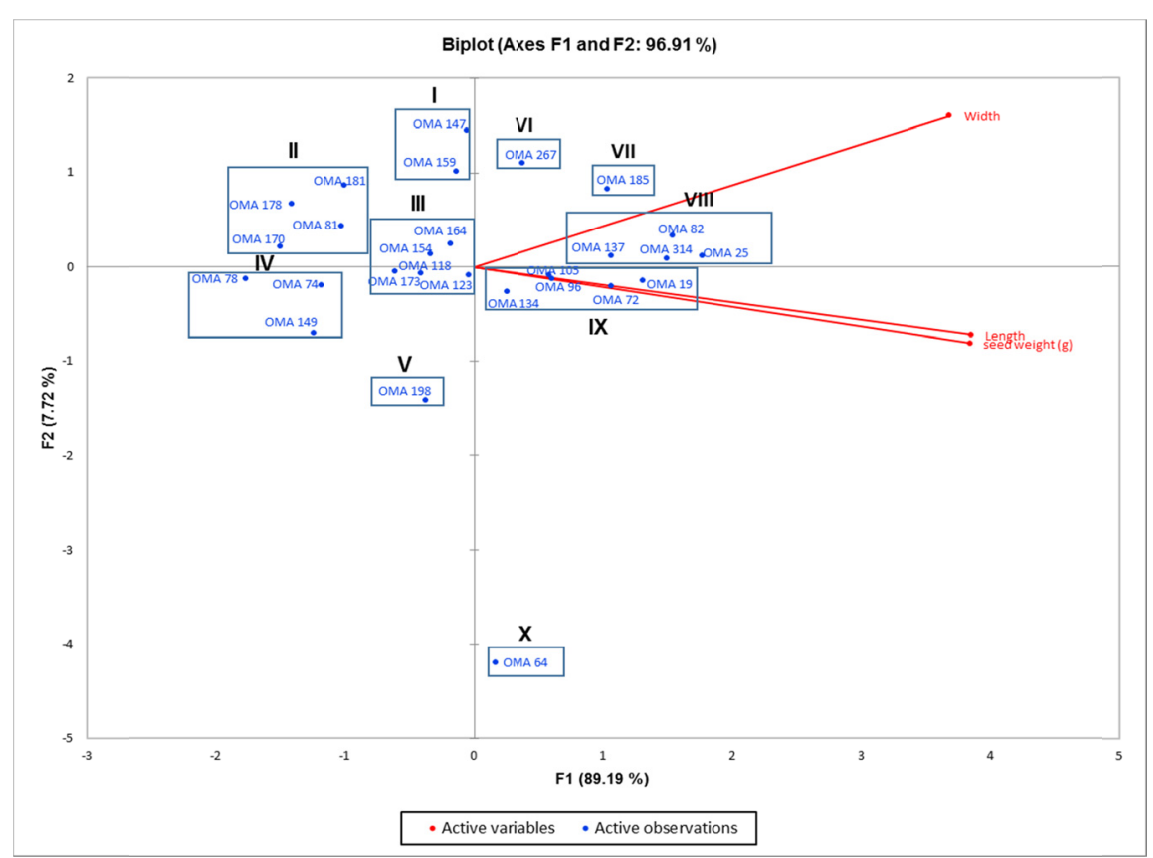

Figure 2. Principal component score of $\mathrm{PC} 1$ and $\mathrm{PC} 2$ describing the overall variation among indigenous field pea germplasm estimated using seed characters 


\section{Discussion}

A range of field pea germplasm was collected during the collecting missions from the most governorates of the Sultanate. South Batinah-coastal governorate represented by Rustaq in the mountains contributed the highest proportions of accessions, collected (55.55\%), followed by Dhahira \& Buraimi governorates with 29.63\% contribution. Governorates of Al-Dakhliyah (Interior) with two accessions accounted to $7.41 \%$ and Sharqiya-eastern area and North Batinah-coastal governorates with one each had the least of $3.70 \%$ contribution. Musandam governorate which is at Northern tip of the Sultanate had no contribution to collections during the collecting missions possibly because of farmers' switch over to greenhouse cultivation of vegetables due to irrigation water shortage in the area.

The critical examination of field pea seed samples at the laboratory showed large variation in seed coat patterns (color) and seed weights to such an extent that the villages located in the vicinity of collecting sites had either similar or different patterns of seed coat color in field pea seed samples/accessions. This indicated that there could be mixture of seeds between the land races during exchange or at harvest during cultivation (Al-Maamari et al., 2014). Seed accessions with heterogeneous seeds with respect to seed coat colors needed intensive purification into sub-groups (AlSaady et al., 2014).

The widespread transfer of landraces of field pea between wilayats and neighboring governorates of the Sultanate of Oman indicated that these landraces/accessions were the products of centuries of selection for adaptation to local climatic, edaphic and cultural factors thus possessing unique gene complexes that arise in the course of evolution (Mathur, 2010; Al-Maamari et al., 2014; AlSaady et al., 2014, 2018a, 2018b). Constant availability of landraces with the farmers having interest to stock with them for cultivation is an indication of existence of local conservation strategy for sustainable production (AlSaady et al., 2014). In the governorates like Al-Musandam where no field pea landraces were obtained and in Al-Dakhliyah, North Al-Batinah-coast and Sharqiyah where lower number of indigenous samples of field pea were found during present collecting missions than the collections made in other collecting missions in the past (Guarino, 1990) indicated the possibility genetic erosion of field pea germplasm. This is attributed to either replacement of landraces by modern high-yielding crops or changes in land use pattern, erratic drought or the lack of interest among current farmers to grow non-commercial crops like field peas.

The correlation analysis of seed characters showed their significant $(\mathrm{p}<0.05)$ and positive associations between each other. Selection of strongly associated characters like seed length and 100 -seed weight can be used to improve seed quality characters that influence yield and their value in marketing as suggested by earlier workers who studied both seed and yield traits in peas for selection of parents in crossing program (Singh \& Srivastava, 2015; Ouafi et al., 2016; Bhuvaneswari et al., 2017; Iqbal et al., 2017).

The results of PCA analysis are useful to the breeders in identifying the phenotypic characters that contribute higher genetic variations among the genotypes for selection of potential parents for crossing to improve the traits of interest for productivity in quantity and quality (Kole et al., 2015; Khan et al., 2016). In the present study, PCA clearly indicated that all the seed traits contributed positively to PCA1 component reflecting the seed size potential of each genotype. Only seed width contributed positively to PCA2 in the present study. The existence of wider phenotypic variability among the indigenous field pea germplasm was further explained by the location pattern of different field pea landraces over all the four quadrants of the biplot graph. This provided an overview of the similarities and differences among the field pea accessions as well as of the interrelationships between the variables, studied. The graph characteristically demarcated the accessions about their scattering pattern based on the first two dimensions/components into 10 clusters based on seed characters in all the four quadrants, indicating wide genetic variability for the traits, studied. The accessions collected from the mountains of Al-Batinah South governorate such as OMA 198 from Alqoorah of wilayat Nakhal and OMA 64 from Haat of wilayat Rustaq were placed at extreme positions from the origin of the graph showing that they are genetically distinct accessions whereas other accessions were more concentrated around the origin of bi-plot graph, indicating their genetic similarity for the seed traits. The fact that accessions of certain clusters were similar or different in terms of their locations showed the extent of inter-exchange of the accessions occurred among the farmers from different governorates. It is advocated that the accessions of different clusters be utilized in crossing program for improvement of seed characters, as these accessions would be expectedly genetically distant.

\section{Conclusions}

27 field pea seed accessions collected during crop collecting missions were found to be spread over major parts of the country and were diverse with respect to seed related traits. These accessions were grouped into 10 
genetically diverse clusters based on the Principal Component Analysis (PCA) using seed traits which revealed significant contribution of seed length $(34.378 \%)$ and 100 -seed weight $(34.182 \%)$ to the total variation existing in indigenous field pea germplasm collected across all the governorates of Oman. The accessions of different clusters could be involved in crossing program for improvement of seed characters.

\section{Acknowledgements}

The authors thank all the concerned Administrative and Academic authorities of Sultan Qaboos University and the Directorate General of Agriculture and Livestock Research for providing the facilities and support for the collecting trip. The financial assistance of H.M. Grants of the Sultan Qaboos University is acknowledged.

\section{References}

Al-Maamari, I. T., Al-Sadi, A. M., \& AlSaady, N. A. (2014). Assessment of genetic diversity in fenugreek (Trigonella foenum-graecum) in Oman. Int. J. Agri. Biol, 16, 813-818.

Al-Saady, N. A., Nadaf, S. K., Al-Hinai, S. A., Al-Subhi, A. S., Al-Farsi, S. M., Al-Habsi, K. M., ... Siddique, K. H. M. (2014). Multicrop Legume Germplasm Collection in Oman. International Journal of Agriculture \& Biology, 16, 231-241.

Al-Saady, N. A., Nadaf, S. K., Al-Lawati, A. H., Al-Hinai, S. A., Al-Subhi, A. S., Al-Farsi, S. M., ... Siddique, K. H. M. (2018a). Fenugreek (Trigonella foenum-graecum L.) germplasm collection in Oman. Int. J. Agri. Innovations and Res. (IJAIR), 6, 212-217.

Al-Saady, N. A., Nadaf, S. K., Al-Lawati, A. H., Al-Hinai, S. A., Al-Subhi, A. S., Al-Farsi, S. M., ... Siddique, K. H. M. (2018b). Germplasm collection in Alfalfa (Medicago sativa L.) in Oman. Int. J. Agri. Innovations and Res., $6,218-224$.

Anonymous. (2018). USDA Grading Standards. US Department of Agriculture, USA.

Bhuvaneswari, S., Sharma, S. K., Punitha, P., \& Shashidhar, K. S. (2017). Evaluation of morphological diversity of field pea [Pisum sativum subsp. arvense (L.)] germplasm under sub-tropical climate of Manipur. Legume Res., 40, 215-223.

Dijkstra, H., \& van Soest, L. J. M. (1986). Descriptor list Pulses; lupines, peas and faba beans (p. 8). CGN, Wageningen.

Egbadzor, K. F., Dadoza, M., Danquah, E. Y., Yeboah, M., Offei, M., \& Ofori, K. (2013). Genetic control of seed size in cowpea (Vigna unguiculata L.) Walp. Int. J. Agric. Sci., 5, 367-371. https://doi.org/10.9735/ 0975-3710.5.2.367-371

Esposito, M. A., Milanesi, L. A., Martin, E. A., Cravero, V. P., Anido, F. S. L., \& Cointry, E. L. (2007). Principal component analysis based on morphological characters in pea (Pisum sativum L.). Int. J. Plant Breed, 1, 135-137.

Gixhari, B., Pavelkova, M., Ismaili, H., Vrapi, H., Jaupi, A., \& Smykal, P. (2014). Genetic diversity of Albanian pea (Pisum sativum L.) landraces assessed by morphological traits and molecular markers. Czech. J. Genet. Plant Breed, 50, 177-184. https://doi.org/10.17221/227/2013-CJGPB

Guarino, L. (1990). Crop collecting in the Sultanate of Oman in the context of Arabian Peninsula. PGR Newsl, $77,27-33$.

Hay, F. R., \& Probert, R. J. (2011). Collecting and Handling in the Field. Collecting plant genetic diversity: Technical guidelines 2011 update. Crop Gene Bank. Retrieved from http://www.cropgenebank.sprp.cgiar. org/index

Hodgkin, T. (1997). Some current issues in conservation of genetic resources. In W. G. Ayad, T. Hodgkin, A. Jaradat, \& V. R. Rao (Eds.), Molecular genetic techniques for plant genetic resources. Report of an IPGRI Workshop, Rome, Italy.

Hoey, B. K., Crowe, K. R., Jones, V. M., \& Polans, N. O. (1996). A phylogenic analysis of Pisum based on morphological characters, and allozyme and RAPD markers. Theoretical \& Applied Genetics, 92, 92-100. https://doi.org/10.1007/BF00222957

IPGRI. (1995). In L. Guarino, V. R. Rao, \& R. Read (Eds.), Collecting Plant Diversity: Technical Guidelines. CABI. 
Iqbal, A., Shah, S., Nisar, M., \& Ghafoor, A. (2017). Morphological characterization and selection for high yielding and powdery mildew resistant pea (Pisum sativum) lines. Sains. Malaysiana, 46, 1727-1734. https://doi.org/10.17576/jsm-2017-4610-08

Khan, M. R. A., Mahboob, M. M., Reza, M. A., Shirazy, B. J., \& Mahmud, F. (2016). Selection of field pea (Pisum sativum L.) genotypes through multivariate analysis. Sci. Agri., 16, 98-103.

Kole, P. R., Sharma, M. K., Kumar, S., \& Kumar, R. (2015). Genetic diversity assessment in Indian cultivated pea (Pisum sativum L.) varieties using RAPD markers. J. Appl. \& Nat. Sci., 7, 316-323. https://doi.org/ 10.31018/jans.v7i1.608

Kumari, P., Basal, N., Singh, A. K., Rai, V. P., Srivastava, C. P., \& Singh, P. K. (2013). Genetic diversity studies in pea (Pisum sativum L.) using simple sequence repeat markers. Genetics and Molecular Research, 12, 3540-3550. https://doi.org/10.4238/2013.March.13.12

MAF. (2005). Agriculture Census-2004-2005. Ministry of Agriculture \& Fisheries, Sultanate of Oman.

MAF. (2017). Annual Agriculture Statistics-2017. Director General of planning and Investment Promotions. Department of Statistics and Information, Ministry of Agriculture \& Fisheries, Oman.

Mafakheri, K., Bihamta, M. R., \& Abbasi, A. R. (2017). Assessment of genetic diversity in cowpea (Vigna unguiculata L.) germplasm using morphological and molecular charcateristics. Cogent Food \& Agriculture, 3, 1327092. https://doi.org/10.1080/23311932.2017.1327092

Mathur, V. L. (2010). Genetic divergence in fenugreek (Trigonella foenum-graecum L.). Indian J. Genetics \& Plant Breeding, 52, 428-432.

Ouafi, L., Alane, F., Rahal-Bouziane, H., \& Abdelguerfi, A. (2016). Agro-morphological diversity within field pea (Pisum sativum L.) genotypes. Afr. J. Agric. Res., 11, 4039-4047. https://doi.org/10.5897/AJAR2016. 11454

Santalla, M., Amurrio, J. M., \& De Ron, A. M. (2001). Food and feed potential breeding value of green, dry and vegetal pea germplasm. Can. J. Pl. Sci., 81, 601-610. https://doi.org/10.4141/P00-114

Simioniuc, D., Uptmoor, R., Friedt, W., \& Ordon, F. (2002). Genetic diversity and relationships among pea cultivars revealed by RAPDs and AFLPs. Plant Breeding, 121, 429-435. https://doi.org/10.1046/j.14390523.2002.733320.x

Singh, A. K., \& Srivastava, C. P. (2015). Effect of plant types on grain yield and lodging resistance in pea (Pisum sativum L.). Indian J. Genet, 75, 69-74.

Syed, A., Lavanya, G. R., \& Gita, K. (2014). Effect of seed size on germination and yield characters in field pea (Pisum sativum L.). International Journal of Agriculture Innovations and Research, 3, 596-598.

Taran, B., Zhang, C., Warkentin, T., Tullu, A., \& Vander-berg, A. (2005). Genetic diversity among varieties and wild species accessions of pea (Pisum sativum L.) based on molecular markers, and morphological and physiological characters. Genome, 48, 257-272. https://doi.org/10.1139/g04-114

Vavilov, N. I. (1951). The Origin, Variation, Immunity and Breeding of Cultivated Plants. Roland Press, New York, USA.

XLSTAT. (2017). Data Analysis and Statistical Solution for Microsoft Excel. Addinsoft, Paris, France.

Yadav, R., Srivastava, R. K., Kant, R., \& Singh, R. (2009). Studies on genetic divergence in field pea (Pisum sativum L.). Legume Res., 32, 21-124.

Zahir, A., Qureshi, A. S., Ali, W., Gulzar, H., Nisar, M., \& Ghafoor, A. (2007). Evaluation of genetic diversity present in pea (Pisum sativum L.) germplasm based on morphological traits, resistance to powdery mildew and molecular characteristics. Pak. J. Bot., 39, 2739-2747.

\section{Copyrights}

Copyright for this article is retained by the author(s), with first publication rights granted to the journal.

This is an open-access article distributed under the terms and conditions of the Creative Commons Attribution license (http://creativecommons.org/licenses/by/4.0/). 